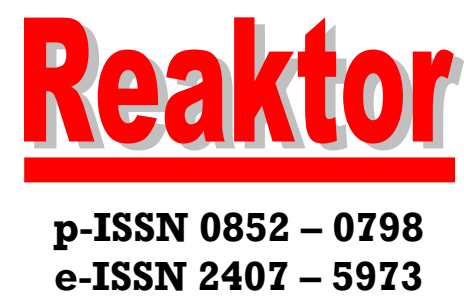

\author{
Acredited: SK No.: 60/E/KPT/2016 \\ Website: http://ejournal.undip.ac.id/index.php/reaktor/
}

Reaktor, Vol. 20 No. 3, September Year 2020, pp. 122-128

\title{
Solely Cellulose-based Adsorbent Derived from Oil Palm Empty Fruit Bunches for Dye Removal
}

\author{
Athanasia Amanda Septevani ${ }^{1 *}$, Farhan Riza Afandi $^{1)}$, Yulianti Sampora ${ }^{1}$, , Yenni \\ Apriliany Devy'), Aisah Resti Amelia ${ }^{2)}$, Melati Septiyanti' ${ }^{1)}$, Dian Burhani ${ }^{3)}$ \\ ${ }^{1)}$ Research Center for Chemistry, Indonesian Institute of Sciences, South Tangerang, Indonesia \\ 2) Eijkman Institute for Molecular Biology, Jakarta, Indonesia \\ 3) Research Center for Biomaterial, Indonesian Institute of Sciences, West Java, Indonesia \\ *) Corresponding author: athanasia.amanda.septevani@lipi.go.id
}

(Received : April 03, 2020; Accepted: August 03, 2020)

\begin{abstract}
The purpose of this research is to determine the adsorption capability of micro and nano-cellulose derived from oil palm empty fruit bunch (EFB) as dye removal. Cellulose based adsorbents were successfully obtained from EFB in the form of microcellulose (eMC) via both delignification (D-eMC) and bleaching processes (B-eMC) as well as in nanocellulose (eNC) by using acid hydrolysis method and hence termed as delignified-eNC (D-eNC) and bleachedeNC $(B-e N C)$ respectively. Dye adsorption test was carried out by UV-Spectrophotometer by comparing initial dye $M O$ concentration (as a control solution) to the treated MO solution upon the addition of micro-and nano-cellulose based adsorbent. It was clear that the dye removal efficiency of micro-cellulose both D-eMC and B-eMC were lower than the nano-cellulose structures. The higher adsorptive capacity of nano-size cellulose compared to the micro-size cellulose was confirmed by the distinct presence of FTIR shifting peak of hydroxyl and sulfonyl groups. It was expected as the micro-size of cellulose would not be able to provide a good adsorptive capability of hydroxyl surface active agent to adsorb the dye. In the case of eNC, the result showed that D-eNC afforded a better dye adsorption than BeNC. At the same concentration of eNC at 3 wt. \%, D-eNC could adsorb at about $19.3 \%$ of MO while only $2.4 \%$ of MO could be removed by B-eNC. Finally, all of adsorbent could maintain $p H$ and TDS within water quality specification.
\end{abstract}

Keywords: adsorption, dye removal, nano-cellulose, oil palm empty fruit bunches, water treatment

How to Cite This Article: Septevani, A.A., Afandi, F.R., Sampora, Y., Devy, Y.A., Amelia, A.R., Septiyanti, M., and Burhani, D (2020), Solely Cellulose-based Adsorbent Derived from Oil Palm Empty Fruit Bunches for Dye Removal, Reaktor, 20(3), 122-128, https://doi.org/10.14710/reaktor.20.3.122-128

\section{INTRODUCTION}

The massive development of the textile industry has significantly increased the production of dyes or synthetic pigments. Although this massive development offers the benefit to the economy, this industry has been responsible for the serious water pollution as $80 \%$ of wastewater comes from the textile industry (Anbia and Salehi, 2012). This waste is difficult to degrade and easy to be accumulated in the environment lead to the 
reduction of water quality and health problems for humans and the ecosystem.

Studies were made to remediate this water pollution via chemical like a photocatalytic system (Rusadi et al., 2018), biological that use enzyme azoreductase as an azo dye degradation, and physical treatments (Shah et al. 2013), Among these methods, adsorption is considered a promising technology because of low-cost, easy and effective operation (Mahmoodi et al., 2010). In particular, the use adsorbents derived from natural materials has been attracted academia to reduce dyes contaminant due to good mechanical strength, resistance to abrasion, as well as the stability of remediation after repeated regeneration and biodegradability (Laraous et al., 2005).

Oil Palm Empty Fruit Bunch (EFB) is one of the solid wastes produced from the palm oil industry. It is reported that at about 7 million tons per year of EFB was generated. There is a limit utilization of EFB which is only $10 \%$ of EFB has been used for boiler and compost fuel, while most of them are discarded or burnt causing serious environmental problem and giving no benefits (Ngadi and Lani, 2014). EFB contains high cellulose about 43\%, hemicellulose 24\%, and lignin $21 \%$ (Septevani et al., 2019; Septevani et al., 2018). The high content of cellulose can be used as a potential advance material due to, low density, low abrasiveness, high biodegradable capability and recently reported as effective adsorption capacity (Septevani et al., 2018; Septevani et al., 2020).

At nanoscale, cellulose possesses a large surface area, exceptional mechanical properties, and low coefficient of thermal expansion (Septevani et al., 2017; Batmaz et al., 2014). In these particular studies, it is reported that nano-cellulose (NC) is a potential ecofriendly adsorbent for dye removal. In previous research showed, NC with sulfonyl group functionality (NCs) that prepared by acid hydrolysis with sulphuric acid displayed a high uptake adsorption capacity for methylene blue dyes with a maximum adsorption capacity was $118 \mathrm{mg} / \mathrm{g}$ at 25 ${ }^{\circ} \mathrm{C}$ and pH 9 (Batmaz et al., 2014). Furthermore, tunability of the adsorption capacity by surface modification of NCs was shown by oxidizing the primary hydroxyl groups on the NCs surface with TEMPO reagent and the adsorption capacity increased from 118 to $769 \mathrm{mg} / \mathrm{g}$ (Batmaz et al., 2014).

This study is aimed on investigating the potential use of micro-cellulose and nano-cellulose derived from oil palm empty fruit bunch (EFB) as the adsorbent of dye contaminant for water remediation. The structureproperty relationship of EFB-based adsorbent was investigated in terms of dye removal, $\mathrm{pH}$ and total dissolved solids (TDS) analysis.

\section{RESEARCH METHODS Materials}

Oil palm empty fruit bunches (EFB) was obtained from PT. Perkebunan Nusantara I, Sumatera Utara, Indonesia. Technical grade sodium hydroxide and hydrogen peroxide were purchased for alkaline pre-treatment and bleaching process respectively. Sulphuric acid $98 \%$ was purchased from Merck for acid hydrolysis. Methyl Orange (4dimethylaminoazobenzene-4'-sulfonic acid) (MO) was purchased from Merck for dye solution.

\section{Preparation Microcellulose (eMC) and Nanocellulose (eNC)}

Both eMC and eNC can obtained from raw EFB through, deliginfication, bleaching, and acid hydrolysis as our previous reported study (Septevani $e t$ al., 2018 and Septevani et al., 2019). The delignification proses was performed in the stirred reactor by adding $\mathrm{NaOH} 10 \%$ wt. into EFB at $150{ }^{\circ} \mathrm{C}$ and 4 bar pressure for 30 minutes. The delignified EFB (D-eMC) was then washed with water to a neutral $\mathrm{pH}$. The D-eMC then went to the bleaching process by using 1 liter $\mathrm{H}_{2} \mathrm{O}_{2}$ and $\mathrm{MgO} 2 \%$ wt. The obtained bleached cellulose, denoted as B-eMC, was then washed with water to a neutral $\mathrm{pH}$ and dried overnight at $50{ }^{\circ} \mathrm{C}$. Both B-eMC and D-eMC was then further hydrolyzed using $36 \%$ of $\mathrm{H}_{2} \mathrm{SO}_{4}$ at $50{ }^{\circ} \mathrm{C}$ for 3.5 hours under vigorous stirring process, followed by neutralization and freeze drier to obtain nanoscale cellulose, denoted as B-eNC and D-eNC, respectively.

\section{Preparation Solution Methyl Orange}

Methyl Orange was chosen as a control solution because MO has azo bonding $(-\mathrm{N}=\mathrm{N}-)$ that normally found in textile dyes and a more difficult to adsorbed than simple dye molecule like methylene blue. Stock solution of $1000 \mathrm{ppm}$ of MO was prepared by dissolving $0.1 \mathrm{gr} \mathrm{MO}$ with $100 \mathrm{ml}$ demineralized aqua. The MO solution was prepared by diluting demineralized water of stock solution to gain concentration $10 \mathrm{ppm}$. For standard solution, the concentration is made from $10 \mathrm{ppm}, 8 \mathrm{ppm}, 6 \mathrm{ppm}, 4$ ppm, and 2 ppm.

\section{Characterization}

Determination adsorption efficiency by using eNC \& eMC adsorption was performed in $50 \mathrm{~mL}$ beaker glass each containing $25 \mathrm{~mL}$ of $10 \mathrm{ppm}$ MO. eNC \& eMC were added to each backer glass with the concentration $0.1 \% ; 0.5 \% ; 1 \% ; 2 \%$; and $3 \%(\mathrm{w} / \mathrm{v})$. These mixtures were stirred using a magnetic stirring bar at $400 \mathrm{rpm}$ for 30 minutes. The treated MO solution was separated by using a filter paper under vacuum condition. The final concentration of $\mathrm{MO}$ after adsorption was measured using Spectrophotometer UV-Vis at $\Lambda_{\max } 465 \mathrm{~nm}$. The adsorbent before and after adsorption was then dried and characterized by IR Prestige 21, Shimadzu. For $\mathrm{pH}$ and TDS analysis, the MO solution before and after the adsorption test was measured using L-AQUA pH/ion/cond. meter F-74 BW, Horriba Scientific.

Hitachi SU3500 with an acceleration voltage of 0.5 $\mathrm{KV}$ was performed in the Research Center for Physisc, LIPI to analysis the morphology of cellulose after treatments. Prior to SEM analysis, the samples were 
coated with gold to provide about $200 \AA$ gold layer thickness using a vacuum sputter coater. At the nanoscale, the morphology of $\mathrm{NC}$ was analyzed by Transmission Electron Microscopy (TEM) at Eijkman Research Institute. The NC suspension was spotted onto a gold glider grid G400G and then stained with $2 \%$ aqueous uranyl acetate. The prepared samples were analyzed in a JEOL 1010 (JEOL, Japan) at 80 $\mathrm{kV}$. The average diameter and length of cellulose fibers were measured using digital image analysis (Image-J) software with a minimum of 10 measurement.

\section{RESULT AND DISCUSSION \\ Synthesis Microcellulose (eMC) and Nanocellulose (eNC) adsorbent}

The delignification process was carried out by dissolving $\mathrm{EFB}$ in $\mathrm{NaOH}$ solution so that some components of lignin, hemicellulose, oil, and wax can be removed from cellulose fibers by increasing the surface accessibility of lignocelulose fibers towards chemicals (Burhani et.al., 2017) and thus enable a greater dissolvability of the lignin and hemicellulose, to produce higher content of cellulose at about $70.12 \%$ (Septevani et al., 2019). The obtained delignified cellulose is thus denoted as D-eMC. The bleaching process was then performed to remove the remaining lignin and hemicellulose in D-eMC using $\mathrm{H}_{2} \mathrm{O}_{2}$ as an environmentally friendly bleaching agent because after the reaction, it decomposes into hydrogen and oxygen with almost no dangerous residues (Bensah and Mensah, 2013). $\mathrm{H}_{2} \mathrm{O}_{2}$ is also strong oxidizing agent so that white and high cellulose at $81.5 \%$ ( denoted as B-eMC) was obtained (Septevani et al., 2019; Septevani et al., 2018). Both B-eMC and D-eMC were then used to produce nano-cellulose through the acid hydrolysis process, and thus denoted as B-eNC and $\mathrm{D}$-eNC respectively.

Figure $1 \mathrm{~A}$ and $1 \mathrm{C}$ show that microsize fibre was obtained after delignification and bleaching. Individual well-separated microsize fibre was observed in the B-eMC while some microfiber bundles were still observed in D-eMC. Further process by acid hydrolysis reduce the size into nanoscale for both D-eNC and B-eNC. The presence of acid will diffuse into the cellulose fibers, and selectively attack the amorphous cellulose by separating the glycosidic bonds leading the acid to reduce the size of the fiber and increase crystallinity (Batmaz et al., 2014; Adiatama et al., 2007). Figure 1B shows that D-eNC possessed a long entangled nanofiber structure with length in microns and diameter in about 10-20 nm. Meanwhile, rod-like nanocellulose was observed in the B-eMC (Figure 1D) with the low aspect ratio of 13 at $10.7 \pm 1.8 \mathrm{~nm}$ in width and $128.4 \pm 17.2 \mathrm{~nm}$ in length. High purity of cellulose after bleaching (BeMC) is postulated to be easier deconstruction into a smaller size compared to D-eMC which still contained complex structure of lignin and hemicellulose (Septevani et al., 2020).
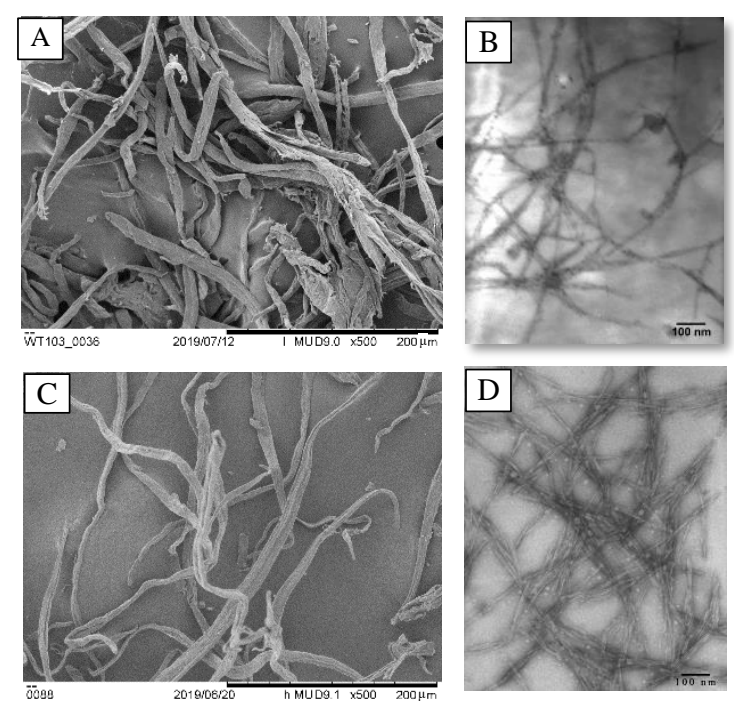

Figure 1. Microscopy of micro and nanocellulose from EFB: A) D-eMC; B) D-eNC; C) B-eMC, and D) B-eNC

\section{Adsorption MO onto EFB-NC}

The adsorption efficiency was determined by using UV spectrophotometry by comparing the concentration of $\mathrm{MO}$ before and after treatment of $\mathrm{EFB}$ adsorbent. Figure 2 shows the adsorption efficiency of EFB-based adsorbents towards MO with varied concentration of adsorbent. Figure 2 clearly showed that the MO adsorption efficiency of micro-cellulose was lower than that of nano-cellulose adsorbent. The maximum adsorption efficiency by using $2 \%$ wt. of BeMC was $1.4 \%$ while $1 \%$ adsorption efficiency was obtained by using D-eMC. Nano scale adsorbent of DeNC was the most effective adsorbent compared to other adsorbents

The increasing concentration of D-eNC was proportional to increasing adsorption efficiency. The addition from 0.1 up to $3 \%$ gradually increased the adsorption efficiency. At the same concentration, $3 \%$ of D-eNC could adsorb up to $19.3 \%$ of MO which was

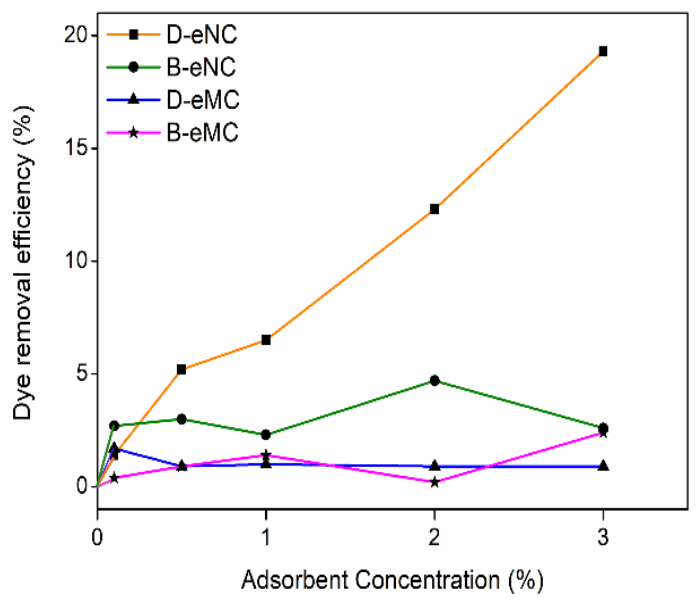

Figure 2. Efficiency adsorption of eNC and eMC 
greater than that of B-eNC at only $2.6 \%$ adsorption efficiency of MO. The greater adsorption ability of DeNC compared to B-eMC, might be attributed to the presence of complex aromatic lignin (at about $12 \%$ in $\mathrm{D}$ eNC, which was much higher than that of B-eNC at only $0.8 \%$ wt.) to offer greater ability of dyes removal. Previous research has been reported that lignin from sugarcane bagasse can adsorb Methylene Blue with an excellent adsorption capacity (Filho et al., 2007). The mechanism of adsorption process of dye removal for methyl orange by the presence of lignin is also reported by Budnyak et al., 2018 due to simultanteously mechanism of electrostatic interaction between positively charge of nitrogen $(\mathrm{N})$ in dye components and dissociated carboxyl and oxygen in the lignin sorbents as well as the hydrogen bounds and $\pi$-interactions during the process. The reported mechanism is illustrated in Scheme 1.

Figure 3 shows the reduction of colour intensity as reflected by reduction absorbance intensity by using the optimum condition of nanocellulose obtain from both bleaching (B-eNC) and delignified (D-eNC) process. It is

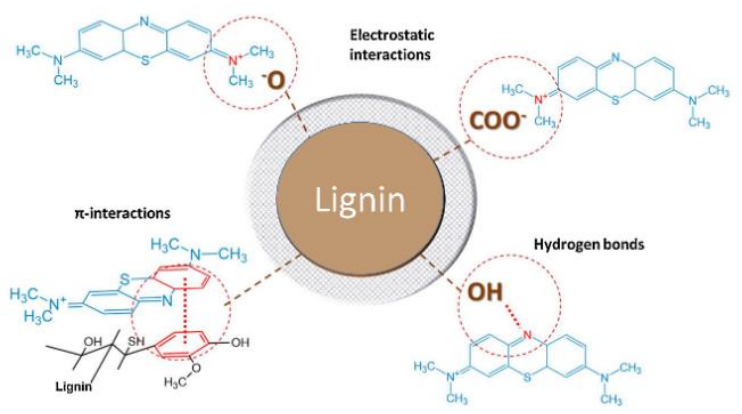

Scheme 1. Reported mechanism of dye adsorption due to the presence of lignin in the adsorbent, adapted from Budnyak et al., 2018

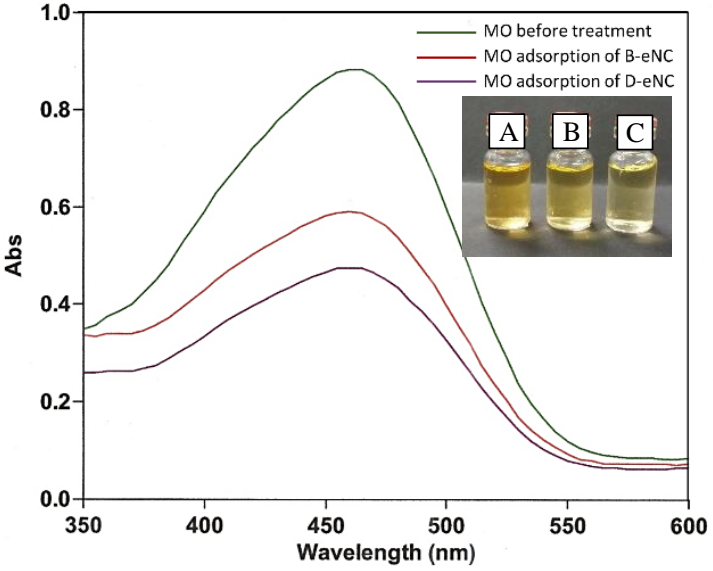

Figure 3. The UV-VIS Absorbance and physical photographs of $\mathrm{MO}$ before (A) and after adsorption of $\mathrm{B}-\mathrm{eNC}(\mathrm{B})$ and D-eNC (C).

clear that the reduction absorbance intensity by using DeNC are higher than B-eNC. The physical color change of control MO (inset Figure 3A) compared to treated $\mathrm{MO}$ after adsorption by using B-eNC (inset Figure 3B) and DeNC (inset Figure 3C) is also in aggrement with the reduction absorbance intensity and illustated in Figure 3. The solution after D-eNC treatment shows a greater change in color towards control MO compared to the solution after B-eNC treatment showing the physical evidence of a greater efficiency as a dye removal for DeNC.

\section{FTIR Analysis}

FTIR spectra for both fresh D-eNC and D-eMC was illustrated in Figure 4. The aliphatic $\mathrm{C}-\mathrm{H}$ group is indicated by a peak of $2895 \mathrm{~cm}^{-1}$ at D-eNC and $2854 \mathrm{~cm}^{-}$

${ }^{1}$ on D-eMC. Lignin is indicated by a peak between 1200 $-1300 \mathrm{~cm}^{-1}$ with aromatic skeletal vibrations (Reddy and Yang, 2005). Both D-eNC and D-eMC indicate the
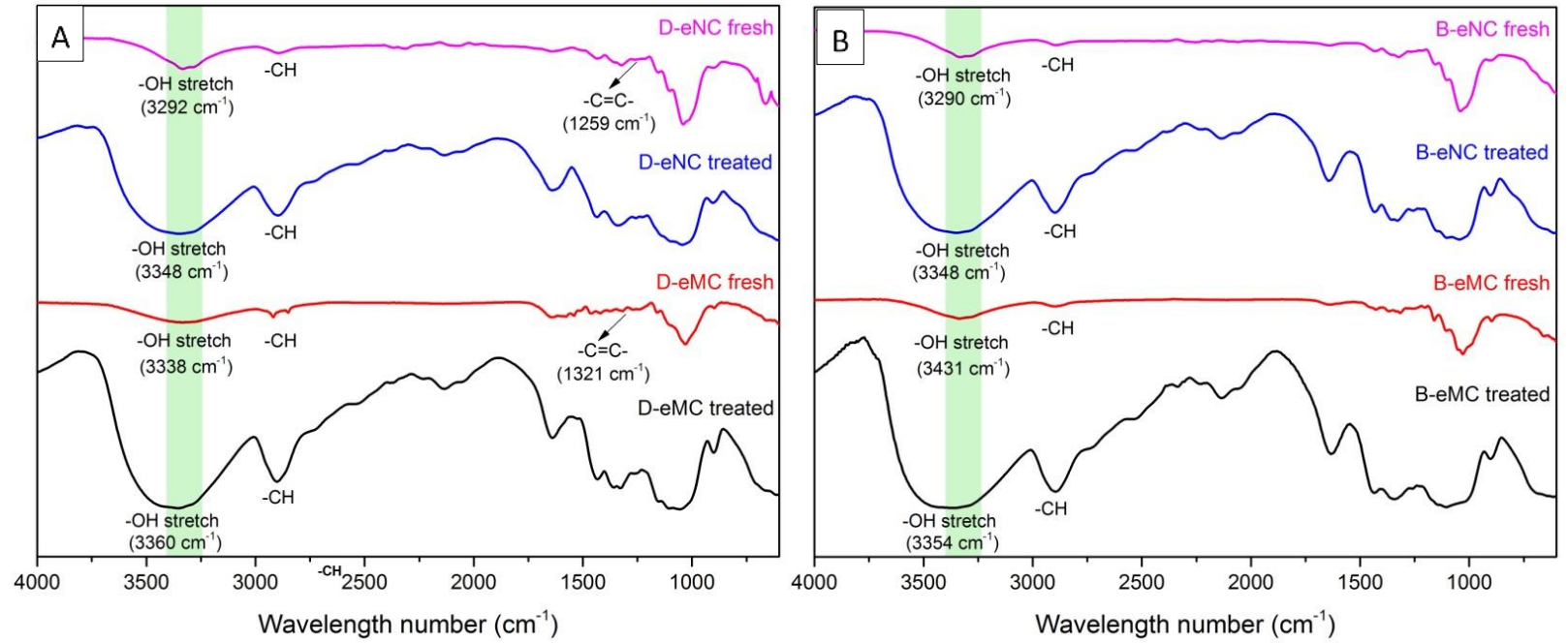

Figure 4. FTIR spectrum of micro and nano-adsorbent from (A) delignification and (B) bleaching process before and after adsorption 
presence of lignin content which is shown at the absorption peak of $1259 \mathrm{~cm}^{-1}$ and $1321 \mathrm{~cm}^{-1}$ respectively. Meanwhile, the aromatic skeletal vibration does not present in B-eMC and B-eNC, which mean that lignin was substantially removed in the bleaching process.

There was a difference in intensity of $-\mathrm{OH}$ stretching. It is seen that the absorption of - $\mathrm{OH}$ stretching at D-eNC $\left(3332 \mathrm{~cm}^{-1}\right)$ was sharper than D-eMC. This sharper absorption of $-\mathrm{OH}$ stretching indicates the presence of intermolecular hydrogen bonds. The breakdown of intermolecular hydrogen from both cellulose and lignin leads to the formation of greater presence of free $-\mathrm{OH}$ groups on the surface of D-eNC as an effective functional group to adsorb MO molecules. In previous research, it has been reported that the mechanism adsorption of the Methylene Blue (MB) can be proposed when MB diffuse through the boundary layer onto the surface of the adsorbent (micro-cellulose). The MB molecules adsorbed on the active site (hydroxyl groups) of the surface and into the interior pores of the micro-cellulose particles (Tan et al., 2018).

The shifting peak at the functional group $-\mathrm{OH}$ stretch on D-eNC spectra was possible because the functional group - $\mathrm{OH}$ after hydrolysis with acid $\left(\mathrm{H}_{2} \mathrm{SO}_{4}\right)$ was protonated to $\mathrm{H}_{3} \mathrm{O}^{+}$(Hardjono, 1991). Protonated conditions indicate that the $-\mathrm{OH}$ bonding character increases in length resulting in a decreased vibration or a shifting in the D-eNC spectra.

The presence of the $-\mathrm{OH}$ bond indicates that the eMC and eNC tend to be more polar indicating the potential to be used as an adsorbent for substances that tend to be polar such as for solution and gas (Wardono et al., 2019). A shifting in the peak absorption of $-\mathrm{OH}$ stretching on the fresh D-eNC (before adsorption) at 3332 $\mathrm{cm}^{-1}$ compared to the $-\mathrm{OH}$ stretching on the D-eNC after adsorption, (denoted as treated D-eNC) at $3348 \mathrm{~cm}^{-1}$ was observed. This is presumably because on the surface of treated $\mathrm{D}-\mathrm{eNC}$ in the -OH group originating from lignin and cellulose interacting with adsorbate molecules (dyes) through hydrogen bonds which is detected by shifting the peak of the absorption $-\mathrm{OH}$ stretching. The resulting absorption at $3348 \mathrm{~cm}^{-1}$ on treated D-eNC was broader compared to fresh D-eNC indicating strong intermolecular hydrogen bonding (Silverstein et al., 2005) between cellulose and/or lignin with MO molecule. It is like fresh D-eMC, B-eMC, and B-eNC where the $-\mathrm{OH}$ stretch region were very broad after adsorption, indicating there was hydrogen bonding between adsorbent and adsorbate.

The protonation of eNC after hydrolysis provides a significantly strong electrostatic attraction between the fibers surface and the dye molecules leading to maximum adsorption (Vinoth and Lim, 2005). Hence, the adsorption of eNC for the dye molecule (MO) was possibility attributed to two mechanisms, firstly, an electrostatic attraction between the protonated hydroxyl groups of adsorbents and dyes; and secondly, the interaction between $\mathrm{MO}$ and adsorbents via hydrogen bonding (Ho and Mc Kay, 1999).

\section{pH and TDS properties}

Analysis of $\mathrm{pH}$ level before and after adsorption is illustrated in Figure 5. The $\mathrm{pH}$ level after adsorption by D-eMC and B-eMC slightly increased from 6.04 to 6.14 and 6.34, respectively. Meanwhile, there was a significant decreasing in $\mathrm{pH}$ level on the treated $\mathrm{MO}$ solution for the adsorption by D-eNC and B-eNC at 5.87 and 4.85, respectively. The decreasing of $\mathrm{pH}$ level possibly was attributed to the release of sulphonyl groups on eNC from adsorbent back to MO solution. However, our previous studies showed that the amount of sulphonyl groups release back to the treated water was insignificantly changed (Septevani et al., 2020).

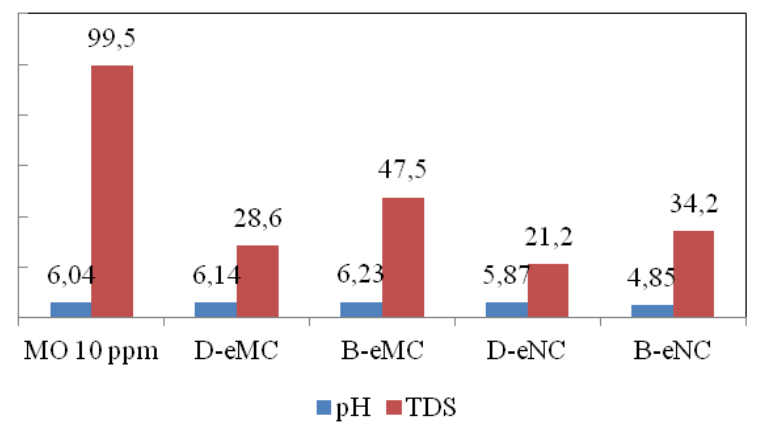

Figure 5. $\mathrm{pH}$ and TDS properties

The results for TDS analysis both eNC and eMC showed that there was a significant decrease in the amount of TDS after adsorption for all the adsorbents which achieved up to $78 \%$ TDS reduction. This indicates the potential application on the use of EFB as an effective adsorbent for organic contaminants. Finally, the results showed that all the adsorbent resulted in the changes of $\mathrm{pH}$ and TDS within the World Health Organization (WHO) specification which are $1000 \mathrm{mg} / \mathrm{l}$ and 6-9, respectively.

\section{Thermogravimetric Analysis}

Thermal stability of cellulose-based adsorbents was investigated by Thermogravimetry Analysis. The initial thermal degradation temperature of eNC based adsorbent was lower than that of eMC based adsorbents. The onset degradation temperature $\left(\mathrm{T}_{\text {onset }}\right)$ of eMC (DeMC and B-eMC) was begun at approximately $285^{\circ} \mathrm{C}$ while for nanocellulose (D-eNC and B-eNC), $\mathrm{T}_{\text {onset }}$ was at about $215{ }^{\circ} \mathrm{C}$. It was expected that the presence of a sulfonyl group upon acid hydrolysis can accelerate the dehydration process leading to a lower initial decomposition temperature (Septevani et al., 2017). Nevertheless, this eNC based-adsorbent is still considered to possess a higher thermal stability at above $200{ }^{\circ} \mathrm{C}$ indicating potential results for the possible treatment at high-temperature contaminant water.

Raw e-EFB possesses a higher thermal stability as a note by lower percentage of weight losses, simply because it still contains many impurities including Silica to give a higher resistance at high temperature (Septevani et al., 2020). 


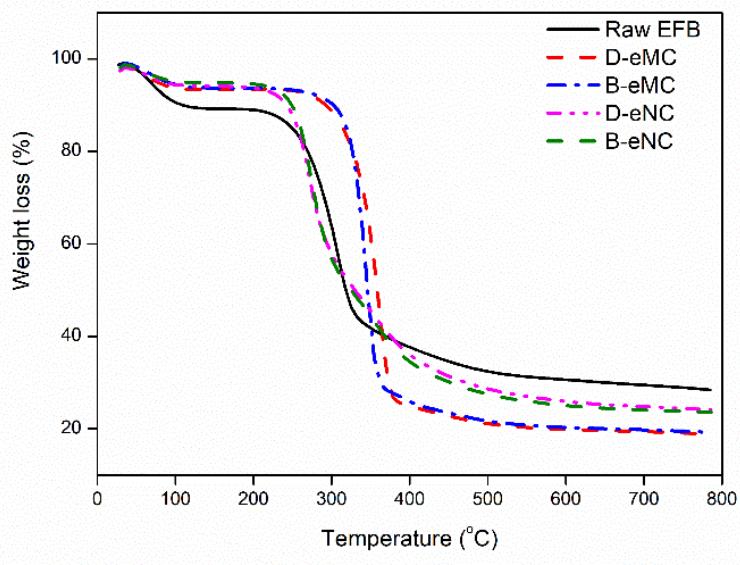

Figure 6. Analysis TGA of adsorbent

Further, eMC based adsorbent (D-eMC and B-eMC) exhibited a single-step and sharp decomposition with a greater weight loss compared to eNC samples (D-eNC and $\mathrm{B}$-eNC). Observed final weight losses for various samples at $700{ }^{\circ} \mathrm{C}$ follow the order: eMC (D-eMC and BeMC) at $\pm 81.5 \%>$ eNC (D-eNC and B-eNC) at $\pm 75.2 \%$ $>$ raw EFB (70.6\%). A greater thermal stability at high temperature of eNC compared to $\mathrm{eMC}$ was possible due to the higher crystallinity of eNC compared to eMC. As earlier discussion, the presence of strong acid upon nanocellulose preparation selectively attack the amorphous cellulose by separating the glycosidic bonds leading the acid to reduce the size of the fiber and increase crystallinity (Batmaz et al., 2014; Adiatama et al., 2007). Our previous reported studies showed that crystallinity of eMC derived from EFB was at about $70-80 \%$ while eNC exhibited $86-96 \%$. It is known that ordered domain found in crystal structure would provide unique and outstanding properties include mechanical, optical and thermal properties, which expected to give a greater thermal degradation at higher themperature in this study.

\section{CONCLUSION}

The adsorption capability of adsorbent based on empty fruit bunches towards dye contaminant of methyl orange was throughly studied at room temperature. The effect of the adsorbent concentration for both eNC and eMC was investigated. Nanosize cellulose provide a greater adsorption capability compared to micro-size cellulose. Based on the UV-VIS Spectra, at the same adsorbent concentration, D-eNC which could adsorb a greater MO compared to B-eNC. The lignin and cellulose structure from D-eNC plays an important role in the mechanism in the adsorption of dye, which was postulated due to electrostatic mechanism as supported by FTIR analysis. Further, the eMC adsorbent showed an insignificant increase in $\mathrm{pH}$ level, while a decrease in $\mathrm{pH}$ level was observed by eNC which was attributed to the sulfonyl release. In terms of TDS analysis, both eMC and eNC resulted in a decreasing TDS value after adsorption indicating a potential use of EFB as eco-friendly based adsorbent for organic contaminant remediations.

\section{ACKNOWLEDGEMENT}

The authors gratefully acknowledge the financial support of Global Research Funds IERI, South Korea 2019. The authors gratefully acknowledge the facilities and scientific and technical assistance of the Microscopy and Microanalysis of Research Center for Physics-LIPI.

\section{REFERENCES}

Adiatama, A.G., Farid, M., and Ardhyananta, H., (2017), Isolasi Selulosa dari Serat Tandan Kosong Kelapa Sawit untuk Nano Filler Komposit Absorpsi Suara: Analisis FTIR, Jurnal Teknik ITS, 6(2), pp. 228-231.

Anbia, M., and Salehi, S., (2012), Removal of acid dyes from aqueous media by adsorption onto aminofunctionalized nanoporous silica SBA-3, Dyes and Pigments, 94(1), pp. 1-9.

Batmaz, R., Mohammed, N., Zaman, M., Minhas, G., Berry, R.M., and Tam, K.C., (2014), Cellulose nanocrystals as promising adsorbents for the removal of cationic dyes, Cellulose, 21, pp. 1655-1665.

Bensah, E. C., and Mensah, M., (2013), Chemical Pretreatment Methods for the Production of Cellulosic Ethanol: Technologies and Innovations," vol. 2013, 2013.

Budnyaka., T.M., Aminzadeh, S., Pylypchukd, I.V., Sternike., D

Tertykh, V.A., Lindström, M.E., Sevastyanova, O., (2018), Methylene Blue dye sorption by hybrid materials from technical lignins, Journal of Environmental Chemical Engineering 6,pp. 49975007

Burhani, D., A. Mauliva, H. Putri, J. Waluyo, Y. Nofiana, dan Y. Sudiyani., (2017), The Effect of TwoStage Pretreatment on the Physical and Chemical Characteristic of Oil Palm Empty Fruit Bunch for Bioethanol Production, In The 3rd International Symposium of Applied Chemistry 2017, American Institute of Physics. doi: https:doi.org/10.1063/1.5011873

Dong, X.M., Revol, J.V., and Gray, D.G., (1998), Effect of Microcrystalline Preparation Conditions on the Formation of Colloid Crystals of Cellulose, Cellulose, 5, pp. 19-32.

Filho, N.C., Venancio, E.C., Barriquello, A.A.W., Hechenleitner, M.F., and Pineda, E.A.G., (2007), Methylene blue adsorption onto modified lignin from sugarcane bagasse, Ecletica Quim, 32(4), pp. 63-70. Ho, Y.S., and Mc Kay, G., (1999), Pseudo-second Order Model for Sorption Process, Process Biochemistry, 34(5), pp. 451-465. 
Laraous, S., Meniai, A.H., and Lehocine, M.B., (2005), Experimental study of the removal copper from aqueous solutions by adsorption using sawdust, Desalination, 185(1), pp. 483-490.

Mahmoodi, N.M., Hayati, B., and Arami, M., (2010), Textile Dye Removal from Single and Ternary Systems Using Date Stones: Kinetic, Isotherm, and Thermodynamic Studies, Journal of Chemical \& Engineering Data, 55, pp. 4638-4649.

Ngadi, N., and Lani, N.S., (2014), Extraction and Characterization of Cellulose Acetate from Empty Fruit Bunch (EFB) Fiber, Jurnal Teknologi, 68, pp. 35-36.

Njanja, E., and Ghogomu, J., (2014), Equilibrium and kinetic modelling of methyl orange adsorption from aqueous solution using rice husk and egussi peeling, International Journal of Chemical Sciences, 12, 741761.

Reddy, N., and Yang, Y., (2005), Structure and properties of high quality natural cellulose fiber from corn stalks, Polymer, 46(15), pp. 5494-5500.

Rusadi, E., Mahatmanti, F.W., and Sulistyaningsih, T., (2018), Preparasi Komposit Kitosan-Bentonit sebagai Adsorben Zat Warna Methyl Orange, Indonesian Journal of Chemical Science, 7(3), pp. 1-7.

Septevani, A.A., Annamalai, P.K., and Martin, D.J., (2017), Synthesis and characterization of cellulose nanocrystals as reinforcing agent in solely palm based polyurethane foam, in AIP Confrence Proceedings, 1904, 020042.

Septevani, A.A., Burhani, D., and Sudiyarmanto, Pengaruh proses pemutihan multi tahap serat selulosa dari limbah tandan kosong kelapa sawit (English: The effect of multistage bleaching process on cellulosic fibre based on oil palm empty fruit bunches), Jurnal Kimia dan Kemasan, 40(2), pp. 71-78.

Septevani, A.A., Burhani, D., Sampora, Y., Sondari, D., Devy, Y.A., Ariani, G.N., and Mohd. Amin, K.N., (2019), The Effect of Acid Hydrolysis Treatment on
The Production of Nanocellulose Based on Oil Palm Empty Fruit Bunches, Jurnal Kimia Terapan, 21(1), pp. 31-37.

Septevani, A.A., Evans, D.A.C., Martin, D.J., and Annamalai, P.K., (2018), Hybrid polyether-palm oil polyester polyol based rigid polyurethane foam reinforced with cellulose nanocrystal, Industrial Crops and Products, 112, pp. 378-388.

Septevani, A.A., Sampora, Y., Burhani, D., Rosa, E.S., Shobih, Sondari, D., Ariani, G.N., Irmawati, Y., Herdiyansyah, A., Devy, Y.A., Ghozali, M., Meliana, Y., Indonesia registered patent, 2019.

Septevani, A.A., Rifathin, A., Sari, A.A., Sampora, Y., Ariani, G.N., Sudiyarmanto, Sondari, D., (2020) Oil palm empty fruit bunch-based nanocellulose as a super-adsorbent for water remediation, Carbohydrate Polymers 229, 115433.

Shah, M.P., Patel, K.A., Nair, S.S., and Darji, A.M., (2013), Isolation, identification and screening of dye decolorizing bacteria, American Journal of Microbiological Research, 1(4), pp. 62-70.

Silverstein, R.M., Webster, F.X., and Kiemle, D.J., (2005), Silverstein - Spectrometric Identification of Organic Compounds, 7th ed., John Willey \& Sons, Inc., USA.

Tan, C.H.C., Sabar, S., and Hussin, M.H., (2018), Development of immobilized microcrystalline cellulose as an effective adsorbent for methylene blue dye removal, South African Journal of Chemical Engineering, 26(8), pp. 11-24.

Vinoth, M., and Lim. H.Y., (2010), Removal of Methyl Orange from Solutions using Yam Leaf Fibers, Int. J. Chem. Tech, 2(4), pp. 1892-1900.

Wardono, H., Naiborhu, T.G., Risano, Y.E., Dyan, M., Amrizal, (2019), Comparison of Utilization of Physical Activated Coconut Shell and Rice Husk Charcoal to Save Fuel Consumption of a 4-Stroke, in Prociding SNTTM 21, 9-10 October. 